\title{
Peran Pengetahuan Gizi Terhadap Asupan Energi, Status Gizi Dan Sikap Tentang Gizi Remaja
}

\author{
Ninda Rizki Aulia *1 \\ ${ }^{1}$ Program Studi Ilmu Gizi, Fakultas Ilmu Kesehatan, Universitas Muhadi Setiabudi Brebes, Indonesia \\ e-mail: 1 nindarizki123@gmail.com,
}

\begin{abstract}
ABSTRAK
Kualitas gizi dan kesehatan pada siklus hidup orang dewasa ditentukann oleh gizi remaja. Status gizi remaja dipengaruhi oleh pengetahuan, sikap dan perilaku gizi remaja. Penelitian ini bertujuan apakah terdapat pengaruh antara pengetahuan gizi terhadap asupan energi, status gizi dan sikap tentang gizi remaja di SMP N 02 Banjarharjo. Penelitian yang dilakukan menggunakan pendekatan crossectional. Jumlah sampel yang digunakan sebanyak 30 orang siswa yang terdiri dari 2 kelas IX di SMP N 02 Banjarharjo dengan menggunakan teknik Random Sampling. Data penelitian didapat menggunakan teknik wawancara untuk mengetahui data pengetahuan gizi dan sikap gizi; kuesioner dalam bentuk formulir food frequency (FFQ) untuk mengetahui data asupan energi; dan pengukuran untuk mengetahui data status gizi siswa. Pengujian statistika bertujuan untuk melihat hubungan antara variabel dependent dan variabel independent dengan menggunakan uji chi Square. Hasil penelitian menunjukkan bahwa terdapat hubungan antara pengetahuan gizi dengan asupan energi $(\mathrm{p}<0,05)$; status gizi siswa $(\mathrm{p}<0,05)$ dan sikap tentang gizi $(\mathrm{p}<0,05)$. Kesimpulan dari penelitian ini terdapat hubungan pengetahuan gizi terhadap asupan energi, status gizi, sikap tentang gizi siswa di SMP N 02 Banjarharjo.
\end{abstract}

Kata kunci: Pengetahuan Gizi, Pola Makan, Status Gizi, Gizi Remaja.

\begin{abstract}
The quality of nutrition and health in an adult's life cycle is determined by adolescent nutrition. The nutritional status of adolescents is influenced by the knowledge, attitudes and nutritional behaviors of adolescents. This study aims at whether there is an influence between nutritional knowledge on energy intake, nutritional status and attitudes about adolescent nutrition at SMP N 02 Banjarharjo. The research was conducted using a crossectional approach. The number of samples used by 30 students consisting of 2 grade IX at SMP N 02 Banjarharjo using Random Sampling technique. Research data obtained using interview techniques to find out data on nutritional knowledge and nutritional attitudes; questionnaire in the form of a food frequency form (FFQ) to find out energy intake data; and measurements to determine the student's nutritional status data. Statistical testing aims to see the relationship between dependent variables and independent variables using the Chi Square test. The results showed that there is a relationship between nutritional knowledge and energy intake ( $p<0.05)$; nutritional status of students $(p<0.05)$ and attitudes about nutrition $(p<0.05)$. The conclusion of this study is the relationship of nutritional knowledge to energy intake, nutritional status, attitudes about nutrition of students at SMP N 02 Banjarharjo
\end{abstract}

Keywords: Nutrition Knowledge, Energy Intake, Nutritional Status, Adolescent Nutrition

\section{PENDAHULUAN}

Perilaku konsumsi pangan manusia ditentukan dari perilaku hidup manusia pada periode remaja. Hal tersebut menjadikan remaja sebagai target pemberian intervensi gizi dengan tujuan meningkatkan status kesehatan perempuan. Siklus hidup perempuan pada periode remaja harus diperhatikan khususnya status gizi remaja karena remaja perempuan dipersiapkan menjadi seorang ibu yang akan melahirkan generasi penerus bangsa yang ungul. Perubahan psikologi, fisiologi, perubahan sosial, pengetahuan dan perilaku gizi yang salah pada remaja akan menimbulkan masalah gizi [1]. Pada periode remaja dengan umur 13-18 tahun memiliki pertumbuhan yang sangat cepat sehingga kebutuhan akan gizi meningkat, selain itu pada periode ini nafsu makan meningkat dan adanya keinginan untuk jajan diluar waktu makan [2]. 
Kelebihan berat badan (overweight) menjadi masalah yang cukup tinggi pada remaja. Overweight dapat diukut menggunalkan indeks massa tubuh terhadap umur yang ditandai dengan nilai $z$-score (IMT/U) >1 SD - 2 SD . Kelebihan berat badan merupakan salah satu penyebab timbulnya penyakit degeneratif dan masalah sosial seperti rendahnya kepercayaan diri. Prevalensi overweight secara nasional di tahun 2013 pada remaja usia 16-18 tahun sebesar 5,7\% sedangkan prevalensi pada provinsi jawa tengah sebesar 5,4\% yang merupakan angka yang cukup tinggi secara nasional [3].. Ketidakseimbangan asupan pangan dengan aktivitas fisik merupakan penyebab overweight dimana kalori yang masuk lebih besar daripada kalori yang dikeluarkan untuk aktivitas fisik yang menjadi pemicu overweight [4].

Pengetahuan gizi yang rendah merupakan salah satu faktor resiko timbulnya masalah gizi dan perubahan kebiasaan makan pada masa remaja [5]. Pengetahuan gizi meliputi pengetahuan terkait makanan dan zat gizi, sumber-sumber zat gizi pada makanan, makanan aman di konsumsi sehingga tidak menimbulkan penyakit dan cara mengolah makanan yang baik agar zat gizi dalam makanan tidak hilang serta bagaimana hidup sehat [6]. Pengetahuan gizi akan mempengaruhi asupan makanan yang masuk kedalam tubuh, karena pengetahuan gizi memberikan informasi yang berhubungan dengan gizi, makanan dan hubungannya dengan kesehatan [5]. Pemilihan makanan yang sehat yang berhubungan dengan pemenuhan gizi seimbang dan kesehatan dipengaruhi oleh pengetahuan gizi remaja [7]. Gaya hidup keluarga juga berkontribusi dalam kebiasaan anak dalam mengkonsumsi makanan terutama dalam hal menyantap makanan siap saji (fast food) [8].

Status gizi adalah sebuah kondisi yang ditentukan oleh tingkat kebutuhan fisik terhadap energi dan zat-zat gizi yang didapatkan dari asupan makanan dengan dampak fisik yang dapat diukur[9]. Status gizi merupakan salah satu indikator baik buruknya penyediaan makanan seharihari, selain itu juga sebagai bentuk ekspresi dari kondisi keseimbangan yang dipresentasikan dalam bentuk variabel tertentu. Status gizi remaja merupakan masalah yang perlu mendapatkan perhatian khusus sebab pengaruhnya besar dalam mkenentukan pertumbuhan dan perkembangan tubuh saat dewasa. Status gizi selain dipengaruhi oleh faktor status kesehatan, pengetahuan, ekonomi, lingkungan dan budaya juga dapat dipengaruhi oleh pola konsumsi energi dan protein [10].

Tingkat pengetahuan gizi seorang remaja akan berpengaruh terhadap sikap dan perilaku dalam memilih makanan, yang menentukan mudah tidaknya seseorang memahami manfaat kandungan gizi dari makanan yang dikonsumsi [10]. Faktor yang mempengaruhi pemilihan makanan jajanan pada anak adalah sikap seorang anak tersebut [2]. Perubahan kebiasaan makan pada remaja diakibatkan oleh pengetahuan gizi yang rendah. Pengetahuan dan praktik gizi remaja yang rendah tercermin dari perilaku dalam kebiasaan memilih makanan yang salah. Remaja yang memiliki pengetahuan gizi yang baik akan lebih memilih makanan sesuai dengan kebutuhannya. Penilaian perilaku gizi remaja diperlukan untuk mengetahui pengetahuan, sikap, dan praktik gizi saat ini dan mengubah perilaku gizi kearah yang lebih baik serta dapat mencegah penyebab penyakit degeneraf[3]. Tujuan penelitian ini adalah untuk menganalisis hubungan antara pengetahuan gizi terhadap asupan zat gizi, status gizi, dan sikap tentang gizi remaja di SMP N 02 Banjarharjo.

\section{BAHAN DAN METODE}

Desain penelitian menggunakan pendekatan crossectional. Jumlah sampel yang digunakan sebanyak 30 siswa yang ada di kelas IX SMP N 02 BANJARHARJO KEC. BANJARHARJO dengan menggunakan metode random sampling. Variabel yang digunakan dalam penelitian ini terdiri dari variabel bebas meliputi pengetahuan gizi dan variabel terikat meliputi asupan energi, status gizi, dan sikap tentang gizi. Pengumpulan data menggunakan teknik wawancara, kuesioner dan pengukuran. Data pengetahuan gizi dan sikap tentang gizi diperoleh menggunakan teknik wawancara; data asupan energi diperoleh menggunakan food frequency quesioner (FFQ) dan data status gizi menggunakan pengukuran tinggi badan dan berat badan. Pengujian hipotesis menggunakan uji chi Square dengan tingkat kepercayaan 95\% untuk 
mengetahui hubungan antara pengetahuan gizi terhadap pola makan, status gizi dan sikap tentang gizi remaja

\section{HASIL DAN PEMBAHASAN}

Responden penelitian ini yaitu anak usia sekolah yang bersekolah di SMP N 02 Banjaraharjo Kecamatan Banjaraharjo Kabupaten Brebes dengan jumlah 30 Orang. Penelitan dilaksanakan di SMP N 02 Banjarharjo dengan alasan sebagian besar siswa yang bersekolah disekolah tersebut berasal dari satu Kecamatan Banjarharjo yang tersebar di seluruh desa yang ada di Kecamatan Banjarharjo. Gambaran Karakteristik responden disajikan pada tabel 1.

Tabel 1. Gambaran Karakteristik Responden

\begin{tabular}{ccc}
\hline Jenis & \multicolumn{2}{c}{ Nilai } \\
\cline { 2 - 3 } & Mean \pm SD & Min - Maks \\
\hline Umur $($ th $)$ & $14,2 \pm 2$ & $13-16$ \\
\hline IMT $\left(\mathrm{kg} / \mathrm{m}^{2}\right)$ & $18,14 \pm 2,6$ & $13,71-29$ \\
\hline
\end{tabular}

Tabel 1 menunjukkan gambaran karakteristik responden dilihat dari umur dan indeks massa tubuh responden. Responden memiliki rentan usia 13-16 tahun dengan rata rata umur 14,2 tahun. Rentang IMT Responden yaitu $13,71-29 \mathrm{~kg} / \mathrm{m}^{2}$ dengan rata rata IMT $18,14 \mathrm{~kg} / \mathrm{m}^{2}$.

Tabel 2. Hubungan Pengetahuan Gizi dengan Asupan Energi siswa

\begin{tabular}{ccccc}
\hline \multirow{2}{*}{ Energi } & \multicolumn{2}{c}{ Pengetahuan Gizi } & Total & Nilai p \\
\cline { 2 - 3 } & Kurang & Baik & & \\
\hline Kurang & 8 & 3 & 11 & $0,002 *$ \\
\hline Baik & 2 & 17 & 19 & \\
\hline Total & 10 & 20 & 30 &
\end{tabular}

Keterangan: $*=$ Ada hubungan antara pengetahuan gizi dengan asupan energi $p<0.005$

Tabel 2 menunjukkan responden dengan Asupan energi kategori kurang berjumlah 11 anak dengan 8 Pengetahuan Gizi kurang sedangkan yang 3 anakdengan Pengetahuan gizi baik. Asupan energi kategori baik berjumlah 19 anak dengan pengetahuan gizi siswa kategori kurang berjumlah 2 sedangkan 17 anak lainnya kategori baik dalam pengetahuan gizi. Hasil analisis chisquare diperoleh nilai $\mathrm{p}<0,005$ (nilai $\mathrm{p} 0,002$ ) yang artinya terdapat hubungan pengetahuan gizi dengan asupan energi siswa di SMP N 02 Banjarharjo. Hal tersebut disebabkan karena pengetahuan gizi akan mempengaruhi konsumsi asupan makanan atau pemilihan makanan yang bergizi atau tidak dalam pemenuhan kebutuhan zat gizi tubuh. Pengetahuan gizi yang diperoleh kemudian diimplementasikan kedalam perilaku dan sikap dalam mengkonsumsi makanan yang akan berakibat ke status gizi. Menurut penelitian yang dilakukan oleh Amellia bahwa Perilaku keluarga sadar gizi (Kadarzi) mempengaruhi status gizi balita [11]. Orang yang sudah mengetahui tentang jumlah, frekuensi, kandungan, jenis, cara pemberian dan manfaat zat gizi akan berusaha memperoleh makanan yang mengandung zat gizi yang sesuai seperti yang dibutuhkan oleh tubuhnya [5].Pengetahuan terlebih dahulu mempengaruhi konsumsi zat gizi. Remaja lebih memilih makanan dengan kandungan natrium dan lemak yang tinggi namun rendah vitamin dan juga mineral. Makanan snack (padat kalori) dan junk food merupakan makanan yang banyak disukai remaja dibanding dengan makanan pokok yang seimbang dan baik dikonsumsi harian. Hal ini menyebabkan tidak terpenuhinya kebutuhan gizi secara optimal pada tubuh remaja. Selain itu jumlah asupan zat gizi yang tidak cukup juga menjadi faktor penyebab masih adanya kategori status gizi kurus pada mahasiswa. Konsumsi karbohidrat, lemak maupun protein yang overload menyebabkan mahasiswa memiliki status gizi berlebih [10]. Energi diperolah dari konsumsi makanan dengan adanya proses pembakaran karbohidrat, protein dan lemak yang kemudian digunakan untuk aktivitas, oleh karena itu penting untuk mengkonsumsi makanan yang cukup dan seimbang [3]. Energi dibutuhkan oleh tubuh untuk mempertahankan hidup, menunjang pertumbuhan, dan melakukan aktivitas fisik [12]. 
Tabel 3. Hubungan Pengetahuan Gizi dengan Status Gizi siswa

\begin{tabular}{ccccc}
\hline $\begin{array}{c}\text { Status } \\
\text { Gizi }\end{array}$ & \multicolumn{2}{c}{ Pengetahuan Gizi } & Total & $\begin{array}{c}\text { Nilai } \\
\text { p }\end{array}$ \\
\cline { 2 - 3 } Kurang & Kurang & Baik & & $0,003^{*}$ \\
Buik & 5 & 0 & 5 & \\
\hline Total & 5 & 20 & 25 & \\
\cline { 2 - 4 } & 10 & 20 & 30 &
\end{tabular}

Keterangan: * $*$ Ada hubungan antara pengetahuangizi dengan status gizi siswa $p<0.005$

Tabel 3 menunjukkan bahwa responden dengan status gizi normal berjumlah 25 anak dengan 5 anak dengan pengetahuan gizi kurang sedangkan yang 20 anak dengan pengetahuan gizi baik. Status Gizi pada kategori tidak normal berjumlah 5 anak dengan pengetahuan gizi siswa kategori kurang berjumlah 5 sedangkan 0 anak lainnya kategori baik dalam pengetahuan gizi. Hasil analisis chi-square diperoleh nilai $\mathrm{p}<0,005$ (nilai $\mathrm{p} 0,003$ ) yang artinya terdapat hubungan status gizi dengan pengetahuan gizi siswa di SMP N 02 Banjarharjo. Hal tersebut disebabkan adanya pengaruh pengatahuan gizi terhadap pemilihan makanan yang akan dikonsumsi. Baik atau tidaknya kualitas makanan yang dipilih dan dikonsumsi berdasarkan kandungan zat gizi akan mempengaruhi status gizi seseorang. Status gizi seseorang tergantung dari asupan makanan, hal tersebut dikarenakan makanan yang dikonsumsi seseorang akan berpengaruh pada zat gizi yang diperoleh oleh tubuh [13]. Status gizi yang kurang baik akan mengakibatkan penurunan prestasi siswa, sejalan dengan penelitian yang dilakukan Masrikhiyah, 2020 menyatakan bahwa status gizi siswa atau remaja akan mempengaruhi prestasi belajar dimana penelitian yang dilakukan di SMP N 02 Songgom menyatakan bahwa status gizi mempengaruhi prestasi belajar Siswa [14].

Tabel 4. Hubungan Pengetahuan Gizi dengan Sikap Siswa

\begin{tabular}{ccccc}
\hline \multirow{2}{*}{$\begin{array}{c}\text { Sikap } \\
\text { Siswa }\end{array}$} & \multicolumn{2}{c}{ Pengetahuan Gizi } & Total & Nilai p \\
\cline { 2 - 3 } Kurang & Baik & & \\
\hline Kurang & 8 & 2 & 10 & \multirow{2}{*}{$0,001^{*}$} \\
\hline Baik & 2 & 18 & 20 & \\
\hline Total & 10 & 20 & 30 & \\
\hline
\end{tabular}

Keterangan: $*=$ Ada hubungan antara pengetahuangizi dengan sikap siswa $p<0.005$

Tabel 4 menunjukkan bahwa responden dengan Sikap kategori kurang berjumlah 10 anak dengan 8 Pengetahuan Gizi kurang sedangkan yang 2 anakdengan Pengetahuan gizi baik. Sikap dengan kategori baik berjumlah 20 anak dengan pengetahuan gizi siswa kategori kurang berjumlah 2 sedangkan 18 anak lainnya kategori baik dalam pengetahuan gizi. Hasil analisis chisquare diperoleh nilai $\mathrm{p}<0,005$ (nilai $\mathrm{p} 0,001$ ) yang artinya terdapat hubungan Sikap dengan pengetahuan gizi siswa siswa di SMP N 02 Banjarharjo. Hal tersebut dikarenakan pengetahuan zat gizi akan mempengaruhi sikap remaja dalam memilih atau mengkonsumsi makanan untuk pemenuhan kebutuhan tubuh. Pengetahuan gizi dapat diperoleh edukasi atau penyuluhan mengenai gizi [15]. Pemenuhan kebutuhan gizi remaja dipengaruhi oleh sikap remaja tentang gizi [5] Sikap seorang anak adalah komponen penting yang berpengaruh dalam memilih makanan jajanan. Sikap dalam memilih makanan jajanan yang baik dapat berpengaruh terhadap kondisi kesehatan seseorang karena dia mampu menerima dan merespon atau menyenangi makanan yang sehat dan bergizi [2]. Hal ini dapat menunjukkan bahwa sikap terbentuk dari komponen pengetahuan dan hal ini akan berpengaruh terhadap perilaku seseorang dalam memilih makanan seimbang. Lingkungan berperan penting dalam sikap remaja, secara khusus untuk memilih makanan sebagai asupan makanan [6]. Perilaku makan yang baik dapat berpengaruh pada kualitas makanan yang dikonsumsi. 


\section{KESIMPULAN}

Terdapat hubungan Pengetahuan Gizi terhadap asupan energi, status gizi, sikap tentang gizi siswa di SMP N 02 Banjarharjo. Pengetahuan gizi yang kurang merupakan awal mula terjadinya masalah gizi pada remaja, dimana pengetahuan gizi berperan penting dalam pemenuhan gizi seimbang.

\section{DAFTAR PUSTAKA}

[1] Nuryani N. Gambaran Pengetahuan, Sikap, Perilaku dan Status Gizi Pada Remaja di Kabupaten Gorontalo. Jurnal Dunia Gizi. 2019 Dec 31;2(2):63-70..

[2] Laenggeng AH, Lumalang Y. Hubungan Pengetahuan Gizi dan Sikap Memilih Makanan Jajanan dengan Status Gizi Siswa SMP Negeri 1 Palu. Healthy Tadulako Journal (Jurnal Kesehatan Tadulako). 2015 Jan 5;1(1):49-57.

[3] Dewi PL, Kartini A. Hubungan Pengetahuan Gizi, Aktivitas Fisik, Asupan Energi, dan Asupan Lemak dengan Kejadian Obesitas pada Remaja Sekolah Menengah Pertama (Doctoral dissertation, Diponegoro University).

[4] Dewi AC, Mahmudiono T. Hubungan pola makan, aktivitas fisik, sikap, dan pengetahuan tentang obesitas dengan status gizi pegawai negeri sipil di kantor dinas kesehatan provinsi jawa timur. Media Gizi Indonesia. 2013;9(1):42-8.

[5] Dewi SR. Hubungan antara pengetahuan gizi, sikap terhadap gizi dan pola konsumsi Siswa kelas XII program keahlian jasa boga di SMK Negeri 6 Yogyakarta. Program Studi Pendidikan Teknik Boga. Fakultas Teknik. Universitas Negeri Yogyakarta. 2013.

[6] Lestari P. Hubungan Pengetahuan Gizi, Asupan Makanan dengan Status Gizi Siswi Mts Darul Ulum. Sport and Nutrition Journal. 2020 Aug 4;2(2):73-80.

[7] Jayanti YD, Novananda NE. Hubungan Pengetahuan Tentang Gizi Seimbang Dengan Status Gizi Pada Remaja Putri Kelas Xi Akuntansi 2 (Di Smk Pgri 2 Kota Kediri). Jurnal Kebidanan. 2017;6(2):100-8.

[8] Myrnawati M, Anita A. Pengaruh Pengetahuan Gizi, Status Sosial Ekonomi, Gaya Hidup Dan Pola Makan Terhadap Status Gizi Anak (Studi Kausal Di Pos Paud Kota Semarang Tahun 2015). Jurnal Pendidikan Usia Dini. 2016 Nov 30;10(2):213-32.

[9] Kanah P. Hubungan Pengetahuan Dan Pola Konsumsi Dengan Status Gizi Pada Mahasiswa Kesehatan. Medical Technology and Public Health Journal. 2020 Sep 25;4(2):203-11.

[10] Safitri NR, Fitranti DY. Pengaruh edukasi gizi dengan ceramah dan booklet terhadap peningkatan pengetahuan dan sikap gizi remaja overweight (Doctoral dissertation, Universitas Diponegoro).

[11] Amellia R, Wahyani AD. Hubungan Perilaku Keluarga Sadar Gizi (Kadarzi) Dan Perilaku Hidup Bersih Sehat (PHBS) Dengan Status Gizi Balita 24-59 Bulan. Jurnal Ilmiah Gizi dan Kesehatan (JIGK). 2020 Aug 31;2(01):18-22.

[12] Sutrio S. Hubungan Asupan Energi, Pengetahuan Gizi Dan Aktivitas Fisik Terhadap Status Gizi Siswa Sekolah Menengah Atas Global Madani Kota Bandar Lampung Tahun 2016. Holistik Jurnal Kesehatan. 2017;11(1):23-33.

[13] Pantaleon MG. Hubungan Pengetahuan Gizi dan Kebiasaan Makan dengan Status Gizi Remaja Putri di SMA Negeri II Kota Kupang. CHMK Health Journal. 2019 Sep 4;3(3):6976.

[14] Masrikhiyah R. Pengaruh Kebiasaan Sarapan Dan Status Gizi Remaja Terhadap Prestasi Belajar. Jurnal Ilmiah Gizi dan Kesehatan (JIGK). 2020 Aug 31;2(01):23-7.

[15] Masrikhiyah R. Peningkatan Pengetahuan Ibu Mengenai Gizi Seimbang Dalam Pemenuhan Gizi Keluarga. Dinamisia: Jurnal Pengabdian Kepada Masyarakat. 2020 Aug $31 ; 4(3): 476-81$. 